\title{
Evaluation of Sympathetic Skin Response and F Wave in Fibromyalgia Syndrome Patients
}

\author{
Fibromiyalji Sendromlu Hastalarda Sempatik Deri Yanıtı ve F Dalgasının Değerlendirilmesi
}

\author{
Tuncay ÇAKIR, ${ }^{1}$ Deniz EVCİK, ${ }^{2}$ Ümit DÜNDAR, ${ }^{1}$ İlknur YİĞİT,,${ }^{1}$ Vural KAVUNCU1 \\ ${ }^{1}$ Department of Physical Medicine and Rehabilitation, Medical Faculty of Afyon Kocatepe University, Afyonkarahisar, Turkey; \\ ${ }^{2}$ Department of Physical Medicine and Rehabilitation, Medical Faculty of Ufuk University, Ankara, Turkey
}

Objectives: This study was planned to perform an electroneuromyographic evaluation of the sympathetic skin response (SSR) and $\mathrm{F}$ wave in order to determine whether there is an autonomic dysfunction in fibromyalgia syndrome (FMS).

Patients and methods: Thirty-eight patients (1 male, 37 females; mean age $40.6 \pm 9.6$; range 22 to 60 years) who were admitted to our clinic between March 2005 and March 2006 and diagnosed with FMS and 30 healthy controls (1 male, 29 females; mean age $39.5 \pm 9.0$ years; range 22 to 55 years) were enrolled in this study. After clinical examination, all patients were evaluated in the electroneuromyography (ENMG) laboratory with respect to SSR and F wave. The $F$ wave was measured in both median and ulnar nerves. The SSR was evaluated in the median nerve. Patients were assessed with respect to the mean value of the $F$ wave distal latency, the distal latency for SSR and the amplitude values. All patients were also evaluated for pain (Visual analogue scale, VAS), number of tender points (NTP), depression (Beck depression inventory, BDI) and functional capacity (fibromyalgia impact questionnaire, FIQ).

Results: No statistically significant difference was found in the distal latency values of the $F$ wave between the groups ( $p>0.05$ ). Fibromyalgia syndrome patients were found to have significantly higher SSR amplitude values and lower latency values for both sides when compared with controls $(p<0.05)$. No statistically significant correlation was found between the SSR (amplitude and latency), and $F$ wave results and the VAS, BDI, FIQ and NTP scores in the patients with FMS ( $p>0.05$ ).

Conclusion: Our results support that, in the sympathetic nervous system of the patients with FMS, there is an alteration that shows the presence of autonomic dysfunction.

Key words: Autonomic dysfunction; F-wave; fibromyalgia; sympathetic skin response.
Amaç: $\mathrm{Bu}$ çalışmada, fibromiyalji sendromu (FMS)'nda otonomik disfonksiyon mevcut olup olmadığının belirlenmesi amacıyla sempatik deri yanıtı (SDY) ve $\mathrm{F}$ dalgasının elektronöromiyografik incelenmesi planlandı.

Hastalar ve yöntemler: Mart 2005 - Mart 2006 tarihleri arasında kliniğimize başvuran ve fibromiyalji sendromu tanısı konulan 38 hasta (1 erkek, 37 kadın; ort. yaş $40.6 \pm 9.6$ yıl; dağılım 22-60 yıl) ve 30 sağlıklı kontrol (1 erkek, 29 kadın; ort. yaş 39.5 \pm 9.0 yıl; dağılım 22-55 yıl) çalışmaya dahil edildi. Klinik inceleme sonrasında tüm hastalar elektronöromiyografi (ENMG) laboratuvarında SDY ve $F$ dalgası açısından değerlendirildi. $F$ dalgası hem median hem de ulnar sinirden ölçüldü. Sempatik deri yanıtı median sinirden değerlendirildi. Hastalar $F$ dalga distal latans ortalaması, SDY distal latans değeri ve amplitüd değerleri açısından değerlendirildi. Tüm hastalar ağrı (görsel analog skalası, GAS), hassas nokta sayısı (HNS), depresyon (Beck depresyon envanteri, BDE) ve fonksiyonel kapasite (fibromiyalji etkisi anketi, FEA) açısından da değerlendirildi.

Bulgular: Gruplar arasında F dalgası distal latans değerleri açısından istatistiksel olarak anlamlı herhangi bir fark bulunmadı ( $p>0.05$ ). Kontrol grubu ile karşılaştırıldığında FMS'li hastaların her iki taraftada daha yüksek SDY amplitüdü değerlerine ve daha düşük latans değerlerine sahip olduğu tespit edildi $(p<0.05)$. Fibromiyalji sendromlu hastalarda SDY (amplitude ve latans) ve $\mathrm{F}$ dalgası sonuçları ile GAS, BDE, FEA ve HNS skorları arasında istatistiksel olarak anlamlı herhangi bir korelasyon tespit edilmedi ( $p>0.05)$.

Sonuç: Sonuçlarımız FMS'li hastaların sempatik sinir sisteminde otonom disfonksiyonu gösteren bir değişiklik olduğunu desteklemektedir.

Anahtar sözcükler: Otonom disfonksiyon; F-dalgası; fibromiyalji; sempatik deri yanıtı. 
Fibromyalgia syndrome (FMS) is a chronic disorder which is characterized by diffuse, widespread pain and the presence of tender points. ${ }^{[1]}$ Various etiologies have been proposed for FMS, but the etiology and pathophysiologic mechanism for diffuse pain is still unknown.

It is possible that several phenomena may play overlapping roles in the development of the syndrome and one of these may be autonomic nervous system (ANS) dysfunction. ${ }^{[2]}$ Pain is the major symptom, and recent studies have considered this to be neuropathic pain related to central nervous system sensitization. ${ }^{[3]}$ Studies have also shown the association of this pain with sympathetic neurotransmitters and increased function in the sympathetic nervous system of FMS patients. ${ }^{[4-6]}$ Stress response plays an important role in the symptoms, and it is believed that the ANS has a close relationship with the efficiency of the stress response and the hypothalamic-pituitary-adrenal axis (HPA). ${ }^{[7]}$

A simple and reliable neurophysiologic method to evaluate the ANS is the study of the sympathetic skin response (SSR) ${ }^{[8,9]}$ Using an electrical stimulation, the eccrine sweat glands of the skin are activated via a reflex loop which includes large, myelinated sensory fibers, central synapses and efferent sympathetic preand post-ganglionic nerve fibers. ${ }^{[9]}$

Fibromyalgia syndrome has complex symptoms and the role of the peripheral nervous system (PNS) in these is not yet clear. Only a few studies have described abnormal electrodiagnostic test results. ${ }^{[10]} \mathrm{F}$ wave is a late response recorded from the muscle elicited by an electric impulse conveyed antidromically to alphamotor neurons in the spinal cord. F wave latency and frequency are assessed to provide information about the proximal segment conduction of the nerves. ${ }^{[1]}$ In this study, F wave is investigated to determine whether the PNS has been affected in FMS.

This study was designed to investigate the electroneuromyographic (ENMG) evaluation of the SSR and F wave in FMS and their correlation with clinical outcomes.

\section{PATIENTS AND METHODS}

The fibromyalgia syndrome group was recruited from the patients admitted to the Physical Medicine and Rehabilitation (PMR) outpatient clinic between March 2005 and March 2006 with widespread musculoskeletal pain. Among 68 patients, 38 (1 male, 37 females; mean age $40.6 \pm 9.6$ years; range 22 to 60 years) meeting the
1990 American College of Rheumatology classification criteria for FMS were enrolled in this study. The control group included 30 healthy volunteers (1 male, 29 females; mean age $39.5 \pm 9.0$; range 22 to 55 years). A total of 75 healthy subjects were screened over a one year period. Fifty subjects without musculoskeletal pain complaint and with no disabling coexisting diseases were eligible for the study. Most of them were accompanying persons of the patients. They were informed about the research, and 20 of them did not approve electrodiagnostics tests. Thirty healthy controls gave written consent and enrolled in this study. After a physical examination, routine laboratory investigations including full blood count, erythrocyte sedimentation rate (ESR) and biochemical markers were carried out. Exclusion criteria for this study were entrapment neuropathies-polyneuropathies (based on electrodiagnostic tests), malignancy, diabetes mellitus, chronic renal failure, and inflammatory joint disease. None of the patients was under medication such as tricylic antidepressants, muscle relaxants or analgesics for at least four weeks before therapy.

\section{Clinical assessment}

The number of tender points (NTP), pain, depression and functional capacity of the patients were evaluated. Tender points were determined by an algometer (Greenwich, USA). Pain was assessed using a $10 \mathrm{~cm}$ visual analog scale (VAS) where 0 corresponded to no pain and 10 to the worst pain. Functional capacity was evaluated by the fibromyalgia impact questionnaire (FIQ) which is a self-administered questionnaire consisting of 10 criteria, including physical function, work status, anxiety, pain, fatigue, sleep, depression, stiffness and well-being. It has different scores for each item and a final calculation was done on a maximum score of $100{ }^{[12]}$ Beck's depression inventory (BDI) was used to evaluate the level of depression. It is also a selfadministered questionnaire and consists of 21 items with a range of $0-63$ where higher scores indicate major depression. ${ }^{[13]}$

\section{Electrodiagnostic testing}

After clinical examination, all patients were investigated in an ENMG laboratory by means of SSR and $\mathrm{F}$ wave. All electrodiagnostic tests were performed by using a Neuropack MEB-2200 Nihon Kohden ENMG apparatus at a room temperature of $26{ }^{\circ} \mathrm{C}$. Before testing, and patients were informed about taking a restful sleep, stopping coffee and alcohol intake.

$\mathrm{F}$ wave studies were performed for median and ulnar nerves bilaterally. The active electrode was placed over 
the middle of the muscle belly of the abductor pollicis brevis for the median nerve and the abductor digiti minimi for the ulnar nerve. The reference electrodes were placed distally. $F$ waves were recorded when the muscle relaxed. At least 20 supramaximal stimulations were applied in a random fashion, and mean $F$ latencies were recorded from each of the extremities.

For measurement of the SSR, the same ENMG equipment was used. The skin temperature was maintained at $32^{\circ}$. Active surface electrodes were attached on the palmar side, and the references were placed on the dorsum of the hand. The stimulus was given at the wrist contralateral to the recording side. Measurements were taken from both arms. An intensity of 20-30 mA with an irregular interval of more than one minute was preferred to prevent habituation. When habituation occurred, stimulation was delayed for about three or four minutes. Skin potentials were recorded for a 10 second analysis period. The latency and peak to peak amplitude were determined. Mean values were used for each parameter. Sweep speed was $500 \mathrm{~ms} / \mathrm{div}$. Sympathetic skin response was considered absent if there was no response after 10 stimulis.

Informed consent was obtained before the examination and the local Ethical Committee of Kocatepe University granted approval for the study.

\section{Statistical analysis}

All parametric results were expressed as mean \pm SD for each group. For the analysis of gender in a matched case control, Mantel-Haenszel odds ratio was used. Statistical analyses were performed using the student $\mathrm{t}$-test to compare mean values of $\mathrm{F}$ wave distal latency and the amplitude and distal latency of SSR between the groups. Results were reported in 95\% confidence intervals. The correlation between the clinical findings and electrodiagnostic tests was analyzed using the Spearman correlation. All analysis were performed using the SPSS (SPSS Inc., Chicago, Illinois, USA) 10.0 version for Windows software program.

\section{RESULTS}

All patients completed the study. No statistically significant difference was found in gender between the groups (odds ratio=1.27). Thirty-three patients in the FMS group and 27 patients in the control group were married. The clinical evaluation of the FMS patients and control group is shown in table 1 .

The results of the blood count and routine biochemical parameters were within normal ranges for both groups.

In the evaluation of SSR, in FMS patients we observed a statistically significant decrease in distal latency, and a statistically significant increase in amplitude, when compared with the control group $(p<0.05)$. However, no statistically significant difference was found in the distal latency of the $\mathrm{F}$ wave between the groups $(\mathrm{p}>0.05)$. The results are shown in table 2 .

There was no statistically significant correlation between the SSR amplitude and distal latency results and VAS, BDS, FIQ and NTP scores in the FMS group ( $\mathrm{p}>0.05$ ). Also, no significant relationship was observed between $\mathrm{F}$ latency and clinical findings ( $>0.05$; Table 3).

\section{DISCUSSION}

The main symptom of FMS is diffuse, chronic pain. Upon clinical examination, no obvious systemic illness is diagnosed. In addition, clinical neurological examination and electrodiagnostic tests including needle ENMG and nerve conduction velocities are normal in FMS. ${ }^{[14,15]}$

\begin{tabular}{|c|c|c|c|c|c|}
\hline & \multicolumn{2}{|c|}{$\begin{array}{l}\text { Fibromyalgia syndrome } \\
\qquad(\mathrm{n}=38)\end{array}$} & \multicolumn{2}{|c|}{$\begin{array}{l}\text { Control } \\
(\mathrm{n}=30)\end{array}$} & \multirow[t]{2}{*}{$p$} \\
\hline & $\mathrm{n}$ & Mean \pm SD & $\mathrm{n}$ & Mean \pm SD & \\
\hline Age (years) & & $40.6 \pm 9.6$ & & $39.5 \pm 9.0$ & 0.707 \\
\hline \multicolumn{6}{|l|}{ Gender } \\
\hline Female & 37 & & 29 & & 0.330 \\
\hline Male & 1 & & 1 & & 0.330 \\
\hline Disease duration (months) & 12 & & & & \\
\hline Visual analog scale & 7 & & & & \\
\hline Beck depression inventory & 15 & & & & \\
\hline Fibromyalgia impact questionnaire & 63 & & & & \\
\hline Number of tender points & 14 & & & & \\
\hline
\end{tabular}




\begin{tabular}{|c|c|c|c|c|}
\hline & $\begin{array}{c}\text { Fibromyalgia } \\
\text { syndrome }(n=38)\end{array}$ & $\begin{array}{l}\text { Control } \\
(n=30)\end{array}$ & $\begin{array}{c}\text { 95\% Confidence } \\
\text { interval }\end{array}$ & $p$ \\
\hline & Mean \pm SD & $\overline{\text { Mean } \pm \text { SD }}$ & & \\
\hline Right median SSR latency (sec) & $1.3 \pm 0.3$ & $1.5 \pm 0.2$ & $0.36-0.08^{*}$ & 0.002 \\
\hline Left median SSR latency (sec) & $1.3 \pm 0.4$ & $1.6 \pm 0.2$ & $0.46-0.18^{*}$ & 0.000 \\
\hline Right median SSR amplitude (mV) & $3.4 \pm 1.9$ & $2.2 \pm 1.4$ & $0.37-2.0^{*}$ & 0.005 \\
\hline Left median SSR amplitude (mV) & $3.2 \pm 1.8$ & $2.3 \pm 1.5$ & $0.13-1.7^{\star}$ & 0.023 \\
\hline Right median F wave latency (ms) & $27.2 \pm 2.1$ & $27.6 \pm 2.6$ & $-1.5-0.7$ & 0.909 \\
\hline Right ulnar F wave latency (ms) & $26.5 \pm 2.2$ & $25.5 \pm 4.7$ & $-0.7-2.7$ & 0.806 \\
\hline Left median F wave latency (ms) & $26.6 \pm 2.2$ & $27.1 \pm 2.7$ & $-1.6-0.6$ & 0.751 \\
\hline Left ulnar F wave latency (ms) & $26.6 \pm 1.9$ & $26.5 \pm 2.3$ & $-0.7-1.2$ & 0.830 \\
\hline
\end{tabular}

Previous studies have investigated the role of autonomic nervous system dysfunction in FMS. The SSR which facilitates examination of the function of the autonomic nervous system simply, practically and effectively has been used extensively. Since the afferent and efferent pathways of the SSR are well known, it has been used in the clinical diagnosis of peripheral autonomic dysfunction for some cases. ${ }^{[16-18]}$

Most of these previously mentioned studies have shown that increased sympathetic nervous system activity, or enhanced responsiveness to sympathetic activity, enhances symptoms in patients with FMS. Some of these studies showed elevated function in the sympathetic nervous system. ${ }^{[4-7]}$ Martinez-Lavin et al. ${ }^{[19]}$ suggested that fibromyalgia patients have norepinephrine-evoked pain which may be resolved by sympatholytic maneuvers. They also proposed that sympathetic hyperactivity may explain some of the manifestations of FMS including sleep disorders, irritable bowel syndrome, sicca symptoms and anxiety. ${ }^{[20]}$ Considering a hypothesis of alteration of muscle and tissue blood flow as well as participation of the sympathetic nervous system, Bennett et al. ${ }^{[21]}$ have demonstrated excess Raynaud's-like symptoms and objective evidence of cold sensitivity in fibromyalgia. Twelve of 29 FMS patients had a decrease in finger systolic pressure of more than $20 \%$ after cooling. Additionally, Bengtsson and Bengtsson ${ }^{[22]}$ have noted that regional sympathetic blocks improved the symptoms.

In our study, fibromyalgia patients had significantly higher amplitudes and lower latencies for both sides when compared with controls. In other words, increased SSR amplitude and decreased SSR latency support the hypothesis of sympathetic nervous system alteration in our FMS patients. Many studies have shown increased amplitude and decreased latency in hemiplegic patients and in reflex sympathetic dystrophy patients as a sign of sympathetic overactivity. ${ }^{[23,24]}$ There are contradictory results regarding SSR latencies. Some studies have reported the intra-individual variations for amplitudes (2-48\%) and latencies (2-22\%). ${ }^{[25,27-30]}$ Although Özgöçmen et al. ${ }^{[25]}$ found a close correlation between SSR latencies

Table 3. Results of the correlation of electrodiagnosting tests and clinical evaluation in fibromyalgia syndrome patients group

\begin{tabular}{lccc}
\hline & & Fibromyalgia sydrome $(\mathrm{n}=38)$ & \\
\cline { 2 - 4 } & SSR (latency) & SSR (amplitude) & F wave latency \\
\hline Visual analog scale & $\mathrm{r}=0.182$ & $\mathrm{p}=0.288$ & $\mathrm{r}=0.218$ \\
& $\mathrm{p}=0.202$ & $\mathrm{r}=0.058$ & $\mathrm{p}=0.738$ \\
Beck depression inventory & $\mathrm{r}=0.053$ & $\mathrm{p}=0.757$ & $\mathrm{r}=0.069$ \\
& $\mathrm{p}=0.690$ & $\mathrm{r}=0.308$ & $\mathrm{p}=0.067$ \\
Fibromyalgia impact questionnaire & $\mathrm{r}=0.192$ & $\mathrm{p}=0.261$ & $\mathrm{r}=0.049$ \\
& $\mathrm{p}=0.778$ & $\mathrm{r}=0.106$ & $\mathrm{p}=0.540$ \\
Number of tender points & $\mathrm{r}=0.122$ & $\mathrm{p}=0.478$ & $\mathrm{r}=0.176$ \\
& $\mathrm{p}=0.322$ & $\mathrm{r}=0.058$ & $\mathrm{p}=0.738$ \\
\hline
\end{tabular}


in hands and clinical parameters, they observed no statistically significant difference in SSR distal latency between FMS patients and controls. In another study, Ulaş et al. ${ }^{[26]}$ investigated the autonomic nervous system dysfunction in FMS patients. They found significantly longer SSR distal latencies which are in contrast with our results. Recently Eisinger ${ }^{[31]}$ reported that "fibromyalgia could be a generalized sympathetic dystrophy". There is an ANS dysfunction in FMS; however, this may not present in the same way for all patients. Some studies support diminished sympathetic activity whereas others found increased activity. These results suggest that there is no accepted point of view, but this does not change the presence of alterations in ANS which our results support.

The F-wave has proven advantages for the evaluation of the conductibility and neuron activity in proximal portions of the motor nerves since the waves occur after impulses have traveled the entire length of the motor nerves. Both $\mathrm{F}$ wave conduction velocity and $\mathrm{F}$ wave occurrence rate reflect the function of motor nerve conductivity and motor neuron activity and have been used recently in the evaluation of peripheral nerve disorders. ${ }^{[32,33]}$ Previously, Ersoz ${ }^{[10]}$ evaluated nerve conduction tests in FMS patients and found no differences in $\mathrm{F}$ wave values performed from median, ulnar, tibial and peroneal nerves. In our study, no significant difference was found in the distal latency of the F wave between the patients and controls.

In conclusion, we can state that increased sympathetic nervous system activation occurs in FMS patients. We suggest that this abnormality could be successfully determined by SSR analysis which can be a useful and noninvasive method.

\section{Declaration of conflicting interests}

The authors declared no conflicts of interest with respect to the authorship and/or publication of this article.

\section{Funding}

The authors received no financial support for the research and/or authorship of this article.

\section{REFERENCES}

1. Wolfe F, Smythe HA, Yunus MB, Bennett RM, Bombardier C, Goldenberg DL, et al. The American College of Rheumatology 1990 criteria for the classification of fibromyalgia. Report of the multicenter criteria committee. Arthritis Rheum 1990;33:160-72.
2. Burkham J, Harris ED. Fibromyalgia: a chronic pain syndrome. In: Harris ED, Budd RC, Firestein GS, Genovese MC, Sergent JS, Ruddy S, et al. editors. Kelley's textbook of rheumatology. 7th ed. Philadelphia: W.B. Saunders 2005. p. 522-36.

3. Martínez-Lavín M. Is fibromyalgia a generalized reflex sympathetic dystrophy? Clin Exp Rheumatol 2001;19:1-3.

4. Martínez-Lavín M, Hermosillo AG, Rosas M, Soto ME. Circadian studies of autonomic nervous balance in patients with fibromyalgia: a heart rate variability analysis. Arthritis Rheum 1998;41:1966-71.

5. Cohen H, Neumann L, Shore M, Amir M, Cassuto Y, Buskila D. Autonomic dysfunction in patients with fibromyalgia: application of power spectral analysis of heart rate variability. Semin Arthritis Rheum 2000; 29:217-27.

6. Cohen H, Neumann L, Alhosshle A, Kotler M, AbuShakra M, Buskila D. Abnormal sympathovagal balance in men with fibromyalgia. J Rheumatol 2001;28:581-9.

7. Petzke F, Clauw DJ. Sympathetic nervous system function in fibromyalgia. Curr Rheumatol Rep 2000;2:116-23.

8. Hirashima F, Yokota T, Hayashi M. Sympathetic skin response in Parkinson's disease. Acta Neurol Scand 1996; 93:127-32.

9. Braune HJ, Korchounov AM, Schipper HI. Autonomic dysfunction in Parkinson's disease assessed by sympathetic skin response: a prospective clinical and neurophysiological trial on 50 patients. Acta Neurol Scand 1997;95:293-7.

10. Ersoz M. Nerve conduction tests in patients with fibromyalgia: comparison with normal controls. Rheumatol Int 2003;23:166-70.

11. Kostera-Pruszczyk A, Rowińska-Marcińska K, Owsiak S, Jezierski P, Emeryk-Szajewska B. F-wave amplitude in peripheral nervous system lesions. Neurol Neurochir Pol 2004;38:465-70. [Abstract]

12. Sarmer S, Ergin S, Yavuzer G. The validity and reliability of the Turkish version of the Fibromyalgia Impact Questionnaire. Rheumatol Int 2000;20:9-12.

13. Beck AT, Ward CH, Mendelson M, Mock J, Erbaugh J. An inventory for measuring depression. Arch Gen Psychiatry 1961;4:561-71.

14. Goldenberg DL. Fibromyalgia syndrome. An emerging but controversial condition. JAMA 1987;257:2782-7.

15. Goldenberg DL. Fibromyalgia in rheumatology. In: Klippel JH, Dieppe PA, editors. Rheumatology. Chapter 16. London; Mosby; 1994. p. 1-12.

16. Yılmaz H, Müftüoğlu-Neyal AM, Özcan AC, İlhan A, Ekmekci H. Migren başağrısında sempatik deri yanıtı. Journal of Turgut Özal Medical Center 1997;4:285-90.

17. Kiylioglu N, Akyol A, Guney E, Bicerol B, Ozkul A, Erturk A. Sympathetic skin response in idiopathic and diabetic carpal tunnel syndrome. Clin Neurol Neurosurg 2005;108:1-7.

18. Gomes I, Nora DB, Becker J, Ehlers JA, Schwartz IV, Giugliani R, et al. Nerve conduction studies, electromyography and sympathetic skin response in Fabry's disease. J Neurol Sci 2003;214:21-5. 
19. Martinez-Lavin M, Vidal M, Barbosa RE, Pineda C, Casanova JM, Nava A. Norepinephrine-evoked pain in fibromyalgia. A randomized pilot study. BMC Musculoskelet Disord 2002;3:2.

20. Martínez-Lavín M, Hermosillo AG. Autonomic nervous system dysfunction may explain the multisystem features of fibromyalgia. Semin Arthritis Rheum 2000; 29:197-9.

21. Bennett RM, Clark SR, Campbell SM, Ingram SB, Burckhardt CS, Nelson DL, et al. Symptoms of Raynaud's syndrome in patients with fibromyalgia. A study utilizing the Nielsen test, digital photoplethysmography, and measurements of platelet alpha 2-adrenergic receptors. Arthritis Rheum 1991;34:264-9.

22. Bengtsson A, Bengtsson M. Regional sympathetic blockade in primary fibromyalgia. Pain 1988;33:161-7.

23. Selçuk B, Ersoz M, Inanir M, Kurtaran A, Akyuz M. Sympathetic skin responses in hemiplegic patients with and without complex regional pain syndrome. Neurol India 2006;54:279-82.

24. Bolel K, Hizmetli S, Akyüz A. Sympathetic skin responses in reflex sympathetic dystrophy. Rheumatol Int 2006; 26:788-91.

25. Ozgocmen S, Yoldas T, Yigiter R, Kaya A, Ardicoglu O. $\mathrm{R}-\mathrm{R}$ interval variation and sympathetic skin response in fibromyalgia. Arch Med Res 2006;37:630-4.
26. Ulas UH, Unlu E, Hamamcioglu K, Odabasi Z, Cakci A, Vural O. Dysautonomia in fibromyalgia syndrome: sympathetic skin responses and RR interval analysis. Rheumatol Int 2006;26:383-7.

27. Akyüz G, Türkdoğan-Sözüer D, Turan B, Canbolat N, Yilmaz I, Us O, et al. Normative data of sympathetic skin response and RR interval variation in Turkish children. Brain Dev 1999;21:99-102.

28. Kucera P, Goldenberg Z, Kurca E. Sympathetic skin response: review of the method and its clinical use. Bratisl Lek Listy 2004;105:108-16.

29. Hoeldtke RD, Davis KM, Hshieh PB, Gaspar SR, Dworkin GE. Autonomic surface potential analysis: assessment of reproducibility and sensitivity. Muscle Nerve 1992;15:926-31.

30. Levy DM, Reid G, Rowley DA, Abraham RR. Quantitative measures of sympathetic skin response in diabetes: relation to sudomotor and neurological function. J Neurol Neurosurg Psychiatry 1992;55:902-8.

31. Eisinger J. Dysautonomia, fibromyalgia and reflex dystrophy. Arthritis Res Ther 2007;9:105.

32. Okuno S, Kobayashi T, Orito K. Usefulness of combined electrophysiological examinations for detection of neural dysfunction in cats with lumbar hematomyelia. J Vet Med Sci 2005;67:1265-8.

33. Koçer A, Gözke E, Dörtcan N, Us O. A comparison of F waves in peripheral nerve disorders. Electromyogr Clin Neurophysiol 2005;45:417-23. 